\title{
Strategies for the Management of Risks in Sports for Sports Administrators in State Sports Councils, South East, Nigeria
}

\author{
Dr. Linda N. Chukwurah \\ Dr. Godfrey C. Nji \\ Mr. Michael Nwokoji \\ Prof. O.A. Umeakuka
}

Department of Human Kinetics, and Health Education, UNN

doi: 10.19044/esj.2017.v13n27p459 URL:http://dx.doi.org/10.19044/esj.2017.v13n27p459

\begin{abstract}
Risks cannot be completely eliminated from sports hence the need to formulate strategies for the management of risks in sports such as risk of injury, risk of financial or monetary loss and risk of damaging of sports facilities. The study involved seven experts. A 33 items Risk Management Strategies for Sports Administrators Questionnaire (RMSSADsQ) was used for data collection. Copies of the questionnaire were given to the experts to rate the appropriateness of the proposed strategies and the data were analyzed using Statistical Package for Social Sciences (SPSS) version 21. 2.50 was used as the criterion mean which implies that any item with less than 2.50 mean score was not considered as a strategy. 30 out of the 33 items were adjudged appropriate as strategies for managing risks in sports. Based on the findings, the researchers therefore recommend that sports administrators should adopt or adapt the formulated risk management strategies in order to enhance effective handling of risks in sports in their various sports councils and organizations.
\end{abstract}

Keywords: Risks, injury, financial loss and damage of sports facilities.

\section{Introduction}

Risks are unavoidable dimension of sports. Risks in sports cannot be completely removed because risks make up greater part of what sports activities are. Risk in sports is the chance of injury, damage or loss for sports organizations; this means the chance of injury to the participants, damage to property or other loss to the organization, directors, volunteers or other (Duch, 2002). According to Miller and Veltri (2003), risk in sports has to do with injury while carrying out sports activities, or financial loss or damage to 
sports facilities. Risks in sports from the above definitions means the possibility of incurring unpleasant result from sports activities depending on the classification or type of risks.

On the classification risks in sports, Ross (2005) classified risks in sports to be risk of injury, loss of reputation, risk of damaging sports facilities and risk of financial loss. Isaac (2009) classified risks in sports as risk of injury, financial or economic loss and risk of damage to sports facilities. This study focused on formulating strategies for the management of risks such as risk of injury, risk of monetary or financial loss and risk of damaging of sports facilities.

Injury is a part of sports activities that cannot be removed completely. According to Liebert (2009), risk of injury stems from the nature of the game and specific activities of the participants both during their participation and during events that surround their participation. For example, collision sports such as football and ice hockey characteristically have more acute traumatic injuries than sports such as swimming and track; boxing has more headrelated trauma because of the focus of the sports. Sports activities are injury prone, though some expose athletes to greater chance of incurring injury. Football for instance involves collision and tackling which increase the possibility of players experiencing serious injuries such as concussion, fracture, among others. Basically, when athletes are injured they will not participate in subsequent competitions or events, when which would negatively affect the performance of the team, especially if the star player is injured. For example; the injury records from the Australian Football Tournament (AFT) (2015) show that over the last 20years, the premiership has usually been won by the teams with the lowest, or one of the lowest injury counts. Also, Hardman and Stensel (2009) stated that an injury to a participation can lead to a lawsuit that will cost the organization and very possibly higher future insurance cost.

Financial loss is another risk sports councils or sports organizations are exposed to. Financial loss in sports occurs when sports councils/organization lose expected income from sports events. Financial loss in sports can be as a result of successful liability cases or teams withdrawing from invited sports events. On withdrawing from sports events, Tymoshenke (2013) reported that Euro Soccer Championship organizers experienced severe financial loss when teams withdrew from the championship in Ukarine. On the other hand, Miles (2013) published a legal case involving Ridolfi Rlett and Trinidad High School sports organizers. The report showed that the school coaches were found guilty after Ridolfi Rlett suffered concussion during a practice section, and the jury awarded the plaintiff the sum of 11.5million dollars as damages. Also, Miles (2013) published another case in which Las Awaras County Sports administrators in 
Mexico were found liable and lost the sum of 3.1million dollars in compensation. When sports councils lose financially, accomplishment of planned objectives/activities would jeopardized thereby leading to poor productivity of the organization. Kotecki (2009) opined that the effects of financial loss in sports council include; relegation from elite competitions because athletes may leave due to non-payment; loss of human resources; and non-achievement of goals.

Sports facilities are important in the actualization of objectives of sports councils, and damage to sports facilities puts an end to planned activities. Damage to sports facilities can be caused by natural factors such as erosion, storm and flood or vandalization. In the case of natural causes, Orchard (2007) reported that in the year 2006, storm damaged University of Northern Iowa sports and recreation facility leading to stoppage of activities. Collin (2010) reported that flood caused the damage of 5million pounds sports facilities in California; and Queen Elizabeth 11 park multi-use in Christ church, New Zealand, with the capacity of 25,000 people was damaged by the 2010 Canterbury earthquake. On vandalization, The Daily California (2010) recounted that four teens vandalized UC Berkeley sports facilities and the damages caused were estimated to be between 3-5,000 dollars. Similarly, Powell (2014) reported that vandals caused significant damage to sporting facilities at an oval in the Northern Perth suburb of Carine by igniting baseball batting nets, leading to a loss of approximately 60,000 dollars. The present study focused on these risks because they are the risks that are pertinent to sports administrators and sports organizations, including sports councils in Nigeria.

In Nigeria, Solabi (2005) stated that sports organizations and administrators focus more in bringing funds to their organizations without adequate plans on ways to manage risks as they occur in activities. According to Ighodaro (2005), stakeholders in sports industry in Nigeria and West African countries need to see the importance for the administrators not only teach basic skills and techniques in their various sports, but also to ensure that the environment and other logistics are put in place to prevent risks to athletes and the organization. Ighodaro further stated that it is very expedient for sports administrators in Nigeria to have basic knowledge of risk management in sports so as to become aware of their legal roles in order to avert litigations as this will help in the transformation of sports and sports programme in the country. Without adequate and effective risks management in sports, sports administrators would not only expose athletes to preventable risks, but also expose themselves and sports councils to legal cases that may lead to financial loss. Therefore, the prevent effort to formulate risks management strategies for sports administrator in order to minimize the occurrence and effects of risks such as injury, damage of sports facilities and 
financial loss, especially, those in State sports councils, South East, Nigeria, because south east parades notable football clubs such as Enyimba of Aba, Football Club Ifeanyi Uba of Anambra, Rangers FC of Enugu, among others.

Strategies involve different actions for the achievement of a goal. Kvint (2009) defined strategy as a system of finding, formulating and developing a doctrine that will ensure long term success if followed faithfully. To Nickols (2012), strategy refers to a complex web of thoughts, ideas and plans that provides general guidance for specific actions in pursuit of a particular end. Strategy involves plans and actions for reaching a particular goal such as mapping out ways to effectively manage risks of injury, financial loss and damage to sports facilities in sports councils and sports organizations. This is expected to optimize the effectiveness and efficiency of organization and administration of sports councils.

\section{Research Question}

1. What are the strategies that can be formulated to manage risks in sports?

\section{Methods}

The study adopted descriptive survey research design. In order to formulate strategies for the management of risks in sports for sports administrators in State sports councils, South East, Nigeria, copies of the validated instrument titled Risk Management Strategies for Sports Administrators Questionnaire (RMSSADsQ) which contained 33 items on the proposed strategies were given to experts to rate the appropriateness or inappropriateness of the items. The instrument obtained a reliability index of .78 using cronbach alpha correlation coefficient. Statistical Package for Social Sciences (SPSS) version 21 was used for all the data analysis, and been that it's a 4point rating scale, 2.50 was used as the criterion mean. This implies that any item that obtained a mean score of 2.50 and above was considered for inclusion as a strategy. However, any item with less than 2.50 mean score was considered not appropriate for inclusion as a strategy. 
Table 1: Proposed strategies for managing risks in sports $(n=7)$

Items Mean Decision

1. Making playing surfaces to be leveled or even

3.86 A

2. Ensuring that playing surfaces are devoid of sharp objects such as stones, nails, pins, broken bottles, pebbles, etc.

3. Using of appropriate and standard equipment and facilities.

$3.86 \quad$ A

4. Insist that athletes wear correct outfits and protective gears meant for an activity

3.57 A

5. Adherence to and enforcing rules of the game at all times

3.86 A

3.71 A

6. Avoiding the use of rusty equipment and facilities that has been use and dumped for a prolonged length of time

$3.29 \mathrm{~A}$

7. Covering field posts with padding

8. Employing qualified coaches for all sports

9. Employing qualified sports psychologists and fitness coaches

$2.29 \mathrm{~N} / \mathrm{A}$

3.71 A

10. Sports activities should not take place nor continue in the absence of the coach

3.14 A

11. Guiding novice participants closely during activities

$2.29 \mathrm{~N} / \mathrm{A}$

3.57 A

12. Treating injured athletes immediately

13. Incidence reports on injuries should be kept, updated and reviewed periodically

14. Treating injured athletes adequately in order to avoid liability case

3.71 A

15. Athletes should sign waiver form before engaging in sports activities

$3.00 \quad \mathrm{~A}$

3.71 A

3.14 A

16. Standard first aid kits with experienced first aider should always be available

3.14 A

17. Planning activities and competitions properly

3.43 A

18. Insure sports council staff with appropriate insurance policy

19. Co-hosting big sports events in order to share financial burden, loss or gain

3.14 A

$2.43 \mathrm{~N} / \mathrm{A}$

20. Sports councils should athletes with accident insurance coverage

21. Keeping proper account of income and expenditure by sports administrators

2.71

3.29

Purchase standard equipment with focus on durability

23. Proper financial records should be kept in sports councils and reviewed often

$3.14 \quad$ A

24. Ensuring that sports facilities are constructed with quality materials

3.71 A

25. Sports facilities should be properly maintained (changing bolts, nuts, oil, grease, etc when due)

26. Contracts for erecting or renovating sports facilities should not be awarded based on personality or familiarity

3.86 A

2.86 A

27. Installing security alarms round sports facilities and sports councils

3.00 A

28. Employing experienced security men from reputable security firm especially for night duties

29. Installing original solar light to provide constant light for security especially at night

30. Erosion incursion on sports facilities should be checked immediately

3.14 A

31. Repairing of damaged sports facilities immediately

3.43 A

32. Carrying out routine and monthly checks on sports facilities

3.14 A

33. Comprehensive routine reports should be kept on the condition of sports facilities and reviewed periodically

$A=$ Appropriate $N / A=$ Not Appropriate

Data contained in the table show that 30 out of 33 proposed risk management strategies for the sports administrators were adjudged appropriate. This shows that the experts acknowledged that the strategies are 
capable of bringing improvement in ways of managing risks in the State sports councils, South East, Nigeria.

\section{Final package of strategies of managing risks in sports for the Sports administrators.}

\begin{tabular}{|c|c|c|}
\hline Risks in Sports & General Objectives & Strategies \\
\hline Risk of Injury & $\begin{array}{ll}\text { - } & \text { Protect athletes from } \\
\text { preventable injuries. } \\
\text { - } & \text { Reduce the rate and } \\
\text { severity of injuries. } \\
\text { - } \\
\text { Avoid exposing athletes } \\
\text { to unnecessary harm. } \\
\text { Ensure trainings are } \\
\text { appropriately planned } \\
\text { and followed. } \\
\text { Protect the sports } \\
\text { administrators from legal } \\
\text { cases as a result of injury } \\
\text { or injuries. }\end{array}$ & $\begin{array}{l}\text { 1. Sports administrators should ensure } \\
\text { that playing surfaces are even or } \\
\text { leveled at all times. } \\
\text { 2. Sports administrators should always } \\
\text { ensure that grounds-men pick round } \\
\text { playing courts and field after training } \\
\text { or practices. } \\
\text { Using appropriate and standard } \\
\text { equipment and facilities should be } \\
\text { made mandatory in sports councils. } \\
\text { 4. Sports administrators should always } \\
\text { insist that athletes or participants put } \\
\text { on the appropriate outfit and } \\
\text { protective gear during every sports } \\
\text { activity. } \\
\text { Athletes or participants should be } \\
\text { made to adhere to rules of a game. } \\
\text { This could be done by the coach } \\
\text { officiating training sessions strictly by } \\
\text { the standard rules of the game. } \\
\text { Rusty equipment and facilities should } \\
\text { not be used, not even for practices. } \\
\text { 7. Qualified coaches should be employed } \\
\text { by the sports councils. } \\
\text { 8. Only qualified sports psychologists } \\
\text { and fitness coach should be employed } \\
\text { for all sports. } \\
\text { 9. Beginning sports participants should } \\
\text { not be left unsupervised. } \\
\text { 10. Sports administrators should always } \\
\text { ensure that injured athletes are } \\
\text { attended to immediately. } \\
\text { 11. There should be proper documentation } \\
\text { of injuries that occur in sports } \\
\text { councils and reviewed periodically. }\end{array}$ \\
\hline $\begin{array}{l}\text { Risk of } \\
\text { Financial Loss }\end{array}$ & $\begin{array}{l}\text { - To avoid liability cases } \\
\text { against sports } \\
\text { administrators and sports } \\
\text { councils. } \\
\text { - } \quad \text { Reduce financial burden } \\
\text { on sports councils } \\
\text { through insurance policy. } \\
\text { - Avoid unnecessary and } \\
\text { unexplainable expenses. }\end{array}$ & $\begin{array}{l}\text { 1. Sports councils should avoid liability } \\
\text { cases by treating injured athletes or } \\
\text { participants adequately irrespective of } \\
\text { the cost. } \\
\text { 2. Sports administrators and sports } \\
\text { councils should insist that athletes or } \\
\text { participants sign the waiver form } \\
\text { before engaging in sports activities. } \\
\text { This could be achieved by coaches } \\
\text { collecting properly filled and signed } \\
\text { waiver form from the athletes before } \\
\text { activities begin. }\end{array}$ \\
\hline
\end{tabular}




\begin{tabular}{|c|c|c|c|}
\hline & & $\begin{array}{l}7 . \\
7 . \\
8 . \\
9 .\end{array}$ & $\begin{array}{l}\text { Sports councils should ensure that } \\
\text { experienced first aid giver is always } \\
\text { available during practices or events } \\
\text { with well equipped first aid box. } \\
\text { Sports events or competitions should } \\
\text { be properly planned. This could be } \\
\text { done by allocating enough time frame } \\
\text { for planning events. } \\
\text { Sports councils should insure their } \\
\text { sports administrators with the } \\
\text { appropriate insurance coverage or } \\
\text { policy. } \\
\text { Accidents insurance coverage should } \\
\text { be provided for athletes in sports } \\
\text { councils. This would help to } \\
\text { adequately treat athletes with severe } \\
\text { or life-threatening injury without } \\
\text { considering the cost. } \\
\text { Sports councils should insist that } \\
\text { sports administrators keep proper } \\
\text { account of their income and } \\
\text { expenditure. This would assist in } \\
\text { keeping track of money spent and the } \\
\text { purpose. } \\
\text { Sports administrators should always } \\
\text { insist on durable sports equipment and } \\
\text { facilities. } \\
\text { There should always be detailed } \\
\text { financial records in sports councils } \\
\text { and reviewed periodically. }\end{array}$ \\
\hline $\begin{array}{l}\text { Risk of } \\
\text { Damaging } \\
\text { Sports } \\
\text { Facilities }\end{array}$ & $\begin{array}{l}\text { Avoid frequent damage, } \\
\text { repairs and purchase of } \\
\text { facilities. } \\
\text { Preventing vandalization } \\
\text { of sports facilities. } \\
\text { Avoid further damage of } \\
\text { and prevent abandoning } \\
\text { of sports facilities. }\end{array}$ & $\begin{array}{l}1 . \\
2 . \\
3 . \\
4 . \\
5 . \\
6 . \\
7 . \\
8 . \\
6 .\end{array}$ & $\begin{array}{l}\text { Sports administrators should insist on } \\
\text { the use of quality material in } \\
\text { constructing sports facilities. } \\
\text { Sports facilities should be maintained } \\
\text { properly. This would prolong the life- } \\
\text { span of the facilities. } \\
\text { Guided by prescribed standard, trusted } \\
\text { construction companies should be } \\
\text { given the contract of erecting or } \\
\text { renovating sports facilities. } \\
\text { Security alarms should be installed in } \\
\text { sports councils and around sports } \\
\text { facilities. } \\
\text { Experienced security men should be } \\
\text { employed from reputable security firm } \\
\text { to guard sports facilities and sports } \\
\text { councils especially at nights. } \\
\text { Original solar light should be installed } \\
\text { round the sports councils and sports } \\
\text { facilities to aid security at night. } \\
\text { Sports councils should not delay in } \\
\text { checking erosion incursion around } \\
\text { sports facilities. } \\
\text { Sports administrators should ensure } \\
\text { that damaged sports facilities are } \\
\text { properly repaired immediately. }\end{array}$ \\
\hline
\end{tabular}




\begin{tabular}{|l|r|r|}
\hline 9. & $\begin{array}{l}\text { Sports administrators should always } \\
\text { carry out routine check on sports } \\
\text { facilities. }\end{array}$ \\
10. $\begin{array}{l}\text { There should always be } \\
\text { comprehensive reports on the } \\
\text { condition of sports facilities kept in } \\
\text { the sports councils and periodically } \\
\text { reviewed. This would assist sports } \\
\text { councils to always know the status of } \\
\text { sports facilities and determine when } \\
\text { repairs, renovation or purchase is } \\
\text { needed. }\end{array}$ \\
\hline
\end{tabular}

The final package of the strategies for managing specified risks in sports were mapped out after removing all items in the formulated strategies that did not obtain up to 2.50 and above criterion mean (decision mean). Also, items in the final package were carefully mapped out in simple forms (languages and terms) that sports administrators would easily understand and apply them effectively.

\section{Recommendations}

Sports administrators in Nigeria, especially, those in State sports councils, South East, Nigeria, should endeavor to utilize the formulated strategies for managing risks such as injury, financial or monetary loss and damage to sports facilities. This would minimize the occurrence of risks in sports and ensure effective risks management in sports generally.

\section{References:}

1. Collin, E. (2010). Government rejects Auckland Common Wealth Games support. UK: The Press

2. Duch, T. (2002). Sports management: Cutting the edge strategies for managing sports as a business. Canada: Toronto

3. Hardman, A. \& Stensel, D. (2009). Physical injury and performance: The evidence explained. London: Routledge

4. Ighodaro, O. U. (2005). Tort liability in sports performance: Implication for coaches of sports in Nigerian University. Sports Complex, University of Benin, Benin City

5. Kotecki, V.I. (2009). Sports advertising handbook: ideas on flight. Seattle: Wagonia Publisher

6. Kvint, V. (2009). The global emerging market: Strategic management and economics. England: Routledge.

7. Liebert, P.L. (2009). Overview of sports injuries. New Jersey: Merek \& Co: Inc.

8. Miles, C.A. (201). Legal battles in sports. The Associate Press 
9. Miller, J. \& Veltri, F. R. (2003). Security issues in public recreation centers. Journal of Legal Aspects of Sports, 12(3): 265-285

10. Nickols, F. (2012). Strategy: Definition and meaning. www.nickols.us/strategy.htm

11. Orchard, A.K. (2007). The orchard sports injury classification system. Clinical Journal of Sport Medicine, 17(3), 201-4

12. Powell, G. (2014). Fire causes $\$ 60,000$ damage to sport facilities in Carina Park. The Daily News

13. Ross, E. W. (2005). Joint injury causes osteoarthritis in young adults. Current Opinion in Rheumatology, 17: 195-200

14. Solabi, A. (2005). Problems in Nigeria sports. Soccer Star, 4, No 21

15. The Daily California (2010). 4 teens vandalized UC Berkeley sports facility. Berkeley News

16. Tymoshenke, Y. (2013). Injuries affect team performance. www.ncibonhure/m.nib/gov.pubmed/2364832 